\title{
BOEKRESENSIE
}

\section{Vredefortkoepel in tyd van oorlogsgeweld}

VE d'Assonville, Generaal De Wet in die Vredefortkoepel, (Marnix, Pretoria, 2010). ISBN: 978-0620-46619-6 Prys: onvermeld. Pp. 239. Sagteband, geïllustreer, bibliografie, register, lys van foto's en afdrukke. Met teksverwysings.

D'Assonville is 'n afgetrede teoloog en hoogleraar aan die voormalige PU vir CHO (tand Noordwes Universiteit). Hy het verskeie teologiese boeke geskryf en is ook die outeur van biografieë, onder andere oor die digter Totius en S.J. Du Toit. Die Afrikaanse volksgeskiedenis het hy in die boeke Bloedrivier, Majuba, Kruger en Rhodes, Op die bodem van die Vaaldam en Eugène Marais en die Waterberge opgeteken.

Die skrywer, 'n grondeienaar in die Vredefortkoepel, het in hierdie publikasie die herinneringe van generaal Christiaan de Wet, saam met die verloop van die Anglo-Boereoorlog langs die Vaalrivier opgeteken. Interessante gebeure soos: die meule van Mac Kensie wat vyf vragte koring vir die boere gemaal het; die slag van die meulwaens, $7 \mathrm{~km}$ wes van Vredefort; generaal De Wet se veilige kamp by Renosterpoort langs die Vaalrivier; verkenners wat 200 opgesaalde Engelse perde gekaap het en die Engelse heliograafseine ontsyfer het, word in hierdie hoogs leesbare werk beskryf. Die dramatiese deurtogte deur Schoemansdrif, Van Rensburgdrif, Skandinawiëdrif, Winkelsdrif, Smitsdrif, Koolmynsdrif, Lindequisdrif en De Wetsdrif word met die nodige spanning oorvertel.

D’Assonville het die veldslae van Tygerpoort, Vanvuurenskloof, Buffelshoek, Groenkop, Heuningkoppies, Rooiwal, Tweebos en Koedoesfontein waar De Wet en sy kommando kwaai onder die grofgeskut van die Engelse deurgeloop het, in detail beskryf. Die wêreld in die Vredefortkoepel - die dorpies Vredefort, Venterskroon en Reitzburg, en die plase Tygerfontein, Leeufontein, Rietfontein, Schoemanshof, Rooikraal, Lindequesfontein en Vlakkuil - is die milieu waarbinne generaal De Wet en sy manne 'n verbete stryd teen 'n oorweldigende militêre mag gevoer het. Daar het bomme geval, koeëls gereën, voorrade gebuit, benoude oomblike ervaar en wegkom planne beraam. Die Engelse se magteloosheid om die Boere te verslaan, hulle beleid van die verskroeide, konsentrasiekampe (Vredefortwegkamp) en die wegvoer van mans na die Britse eilande is die koepelbewoners nie gespaar nie. Die foto's, afdrukke en kaarte is toepaslik en

komplimenteer die teks op die toepaslike plekke. Verder verleen die register met persons- en plekname aan die einde, meer waarde aan die publikasie.

Nuwe belangstelling in die streek het veral ná 2005 gekom, toe die United Nations Educational, Scientific and Cultural Organization (UNESCO) se wêrelderfenisbewaringsprogram die Vredefortkoepel op die lys van wêrelderfenisgebiede geplaas het. Hierdie boek is 'n uitstekende kultuurhistoriese bron oor die Anglo-Boereoorlog in die Vredefortkoepel. Dit is ook van toepassing op die omliggende gebied. Dit word aanbeveel vir enige iemand wat meer oor die geskiedenis van die area wil weet.

\section{Claudia Gouws}

Noordwes Universiteit 